Revista Eletrônica de Direito Processual - REDP.

Rio de Janeiro. Ano 11. Volume 18. Número 1. Janeiro a Abril de 2017

Periódico Quadrimestral da Pós-Graduação Stricto Sensu em Direito Processual da UERJ

Patrono: José Carlos Barbosa Moreira. ISSN 1982-7636. pp. 377-402

www.redp.uerj.br

\title{
FALSOS DISTANCIAMENTOS E REAIS DIFERENÇAS ENTRE COMMON LAW \\ E CIVIL LAW $W^{1}$
}

\section{FALSE DISTANCES AND REAL DIFFERENCES BETWEEN COMMON LAW AND CIVIL LAW}

Túlio de Medeiros Jales

Bacharel em Direito pela Universidade Federal do Rio Grande do Norte (UFRN). Mestre em Constituição e Garantias de Direito pela Universidade Federal do Rio Grande do Norte (UFRN). Doutorando em Direito do Estado pela Universidade de São Paulo.

tulio_jales@hotmail.com; tuliojalesadv@gmail.com

RESUMO: O trabalho defende ser equivocado utilizar supostas distinções ontológicas entre common law e civil law para explicar tanto a diferença de hierarquia normativa entre leis e precedentes quanto uma assimetria metodológica na aplicação desses dois tipos normativos. Desenhando as transformações que o acolhimento da perspectiva pós positivista lança à temática das tradições jurídicas, encampa a hipótese de que a diferença entre as duas famílias jurídicas é fruto do acolhimento de contestáveis teses do positivismo jurídico. A confirmação da hipótese indica a necessidade de buscar alternativas para explicar diferenças entre ordenamentos jurídicos que não estejam fundadas nas categorias das tradições jurídicas.

PalavraS-Chave: Civil Law. Common Law. Pós Positivismo. Convergência de Tradições Jurídicas.

ABSTRACT: The paper argues that it is wrong to use supposed ontological distinctions between common law and civil law to explain both the difference of normative hierarchy between laws and precedents and a methodological asymmetry in the application of these two normative types. Drawing the transformations that the reception of the post positivist

\footnotetext{
${ }^{1}$ Artigo recebido em 08/02/2017 e aprovado em 25/04/2017.
} 
Revista Eletrônica de Direito Processual - REDP.

Rio de Janeiro. Ano 11. Volume 18. Número 1. Janeiro a Abril de 2017

Periódico Quadrimestral da Pós-Graduação Stricto Sensu em Direito Processual da UERJ

Patrono: José Carlos Barbosa Moreira. ISSN 1982-7636. pp. 377-402

www.redp.uerj.br

perspective throws at the theme of juridical traditions, it assumes the hypothesis that the

difference between the two legal families is fruit of the reception of contestable theses of the legal positivism. The confirmation of the hypothesis indicates the need to seek alternatives to explain differences between legal orders that are not based on the categories of legal traditions.

KEYWORDS: Civil Law. Common Law. Post Positivism. Convergence of Legal Traditions.

\section{INTRODUÇÃO}

A intenção do artigo é dissipar uma cortina de fumaça produzida por certas abordagens teóricas que pretendem caracterizar o uso de precedentes judiciais em ordenamentos jurídicos a partir de diferenças na natureza, ou na essência das tradições jurídicas do common law e do civil law. Nesse contexto, dois acervos de supostas diferenças se elevam. O primeiro relaciona-se a distinções no reconhecimento de fontes jurídicas em ambas as tradições; o segundo refere a existência de métodos diferenciados para a aplicação e interpretação do direito em cada uma delas. Defendendo o processo de assemelhação entre as famílias jurídicas ${ }^{2}$, o trabalho seguirá a linha da tese da convergência de tradições para sustentar que dessemelhanças entre ordenamentos jurídicos a respeito do reconhecimento e da aplicação do direito judicial não decorrem diretamente da pertença de um sistema à determinada tradição jurídica.

$\mathrm{O}$ argumento fundamental para hipótese é que, desbordando um movimento de convergência, o pós-positivismo jurídico conseguiu desdiferenciar as duas principais famílias jurídicas ocidentais, o que, por implicação, capitulará qualquer intenção de se

\footnotetext{
${ }^{2}$ Em de 1982, Guido Calabresi publicou tese, então inovadora, sustentando estar o sistema do common law estadunidense entrando em um período em que os estatutos legislativos concorreriam de igual para igual com os precedentes na oferta de soluções aos casos jurídicos. Segundo Calebresi, o avanço dos estatutos ocorria em razão das cortes não terem sido capazes de escrever o direito na velocidade reclamada pelo mundo moderno. Ainda mais longínqua, de 1964, é a obra magna de René David na qual o professor francês anteviu a possibilidade de juízes da tradição romano-germânica verem-se obrigados a seguir precedentes ${ }^{2}$. No fim do século XX, em um dos mais importantes estudos comparativos sobre o uso de precedentes entre países de tradição romano-germânica e países de cultura anglo-saxã, Neil MacCormick e Robert Summers insinuam que o contraste metodológico e conceitual entre common law e civil law pode, em verdade, nunca ter existido. Ao longo dos anos, explicações para o sincretismo entre modelos antes vistos como distintos surgiram sob diversos enfoques ${ }^{2}$; a diversidade de elucidações não abalou, contudo, a premissa de que a convergência, de fato, ocorre
} 
Revista Eletrônica de Direito Processual - REDP.

Rio de Janeiro. Ano 11. Volume 18. Número 1. Janeiro a Abril de 2017

Periódico Quadrimestral da Pós-Graduação Stricto Sensu em Direito Processual da UERJ

Patrono: José Carlos Barbosa Moreira. ISSN 1982-7636. pp. 377-402

www.redp.uerj.br

diferenciar ontologicamente a aplicação de precedentes pura e simplesmente a partir da distinção entre cultuas jurídicas.

Dissipados os mal-entendidos nos planos conceitual (fontes) e metodológico (aplicação) entre as duas tradições jurídicas (civil law/common law), o trabalho tem o mérito de abrir espaço para alternativas teóricas que busquem para descrever e justificar distinções entre ordenamentos jurídicos.

\section{APROXIMAÇÕES E DISTANCIAMENTOS NO HORIZONTE CONCEITUAL DAS FONTES JURÍDICAS}

\subsection{Da validade normativa à validade argumentativa das fontes jurídicas}

Uma primeira diferença pontuada entre a resolução de casos nas duas grandes tradições jurídicas ocidentais utiliza-se de uma cisão na situação de validade das normas próprias de cada uma delas. Diante de um caso concreto, civil law e common law responderiam de forma contrastante à pergunta: "qual o direito válido aplicável à hipótese fática?". Para dissertarmos sobre o tema, adotamos a distinção sugerida por Fábio Shecaira ${ }^{3}$ entre fontes do direito e normas jurídicas. Às primeiras corresponderiam os estatutos, precedentes ou costumes, a depender de quais documentos ou materiais fáticos o ordenamento reconheça como válidos para fazer nascer o direito". As normas, por seu turno, seriam as construções surgidas a partir do material fornecido pelas fontes jurídicas em um processo mediado pelos chamados métodos interpretativos ${ }^{4}$. Nesse esquema, a validade de uma norma depende diretamente da validade da fonte de onde ela se origina. Não reconhecida a validade da fonte, impossível reconhecer a validade da norma.

No civil law, pelo fato de leis, códigos e estatutos apresentarem-se como fontes de valor normativo formalmente reconhecido ${ }^{5} \mathrm{e}$, portanto, válidas, estariam as normas oriundas destas fontes em situação de aplicação privilegiada frente às decisões judiciais, que não

\footnotetext{
${ }^{3}$ SHECAIRA, Fábio Perin, Sources of Law are Not Legal Norms. Ratio Juris, v. 28, n. 1, pp. 15-30, 2015. p. $16-18$.

${ }^{4}$ SHECAIRA. op. cit., p. 19.

${ }^{5}$ No direito brasileiro, uma norma que poderia dar sustentação a uma construção nesse sentido está presente no art. $4^{\circ}$ do Decreto Lei no 4657/42, a chamada Lei de Introdução ao Direito Brasileiro: “Art. 4: Quando a lei for omissa, o juiz decidirá o caso de acordo com a analogia, os costumes e os princípios gerais de direito". Como se percebe, a lei, em momento nenhum, reconhece os precedentes ou decisões judicias como fontes formais do direito.
} 
Revista Eletrônica de Direito Processual - REDP.

Rio de Janeiro. Ano 11. Volume 18. Número 1. Janeiro a Abril de 2017

Periódico Quadrimestral da Pós-Graduação Stricto Sensu em Direito Processual da UERJ

Patrono: José Carlos Barbosa Moreira. ISSN 1982-7636. pp. 377-402

www.redp.uerj.br

teriam tal chancela formal. $\mathrm{O}$ precedente, enquanto produto advindo de um material não compreendido como fonte do direito, só teria algum valor normativo na medida em que a própria legislação concedesse. A lógica contrária aplicar-se-ia no common law: a força das decisões judiciais deveria sobrepor ou mesmo tornar desnecessária a existência de estatutos. Enxergado o Judiciário como órgão do qual emana uma fonte jurídica válida, das decisões judiciais poderiam florescer normas autorizadas a justificar outras decisões. Nessa dinâmica da cisão ente as tradições, ou os precedentes só poderiam ser compreendidos na medida autorizada pela legislação ou os estatutos deveriam ser compreendidos segundo o horizonte de significado precedental.

Observa-se, contudo, que a concepção de situações de validades diversas - a depender da tradição em que se esteja mergulhado - está escorada em uma Teoria das Fontes Sociais positivista que já se encontra envolta em um nível de aceitação contestável.

Segundo Bustamante ${ }^{6}$, duas teses marcam o positivismo jurídico contemporâneo: (a) a tese das fontes sociais do direito, pela qual uma dada norma social só é direito se for reconhecida como tal por uma fonte superior imposta pelos titulares do poder social prevalecente $^{7}$ e (b) a tese da separabilidade entre direito e moral, pela qual caracterizar uma norma como jurídica independe de qualquer avaliação de seu conteúdo moral. Para saber se há, de fato, uma diferença conceitual em termos de fontes jurídicas entre as tradições de common law e civil law, deteremo-nos, por ora, em torno da primeira tese. Em razão de a separação entre direito e moral afetar diretamente a operacionalização das normas jurídicas, a segunda tese será aprofundada na seção 3 deste artigo, que cuidará especificamente do ponto de vista metodológico da assemelhação entre as tradições jurídicas.

A tese das fontes sociais é uma qualificação da conhecida tese da regra de reconhecimento hartiana. Para $\operatorname{Hart}^{8}$, a regra de reconhecimento permitiria identificar quais são as regras primárias de obrigação ${ }^{9}$ e se elas são dotadas de validade ou não. Seria ela uma

\footnotetext{
6 BUSTAMANTE, Thomas. A breve história do positivismo descritivo. O que resta do positivismo jurídico depois de h. L. A. Hart? Novos Estudos Jurídicos (Online), v. 20, p. 307-327, 2015.2015, p. 310.

${ }^{7}$ DIMOULIS, Dimitri. A relevância prática do positivismo jurídico. Revista Brasileira de Estudos Políticos. Belo Horizonte, n. 102, pp. 215-253, jan./jun. 2011,p. 236.

${ }^{8}$ HART, Herbert. O conceito de direito. Lisboa: Fundação Calouste Gulbenkian, 1986, p. 120.

9 "No decorrer de sua análise da teoria de Austin, Hart expõe que, a par de regras que denominou de 'regras primárias de obrigação', existem outras que não impõem deveres e que, portanto, se distanciam por completo das ideias de ordens cujo atendimento seja garantido mediante ameaças, demonstrando inclusive que, em sistemas jurídicos evoluídos, existem regras, a que denominou de 'secundárias', que permitem reconhecer quando se está diante de uma regra primária de obrigação, permitem definir como se podem alterar regras primárias de obrigação e permitem solucionar conflitos em torno da incidência ou não de regras dessa natureza
} 
Revista Eletrônica de Direito Processual - REDP.

Rio de Janeiro. Ano 11. Volume 18. Número 1. Janeiro a Abril de 2017

Periódico Quadrimestral da Pós-Graduação Stricto Sensu em Direito Processual da UERJ

Patrono: José Carlos Barbosa Moreira. ISSN 1982-7636. pp. 377-402

www.redp.uerj.br

regra social, uma convenção entre oficiais do sistema jurídico que permitiria reconhecer a

autoritatividade das normas. Caso determinada norma estivesse fora dos critérios impostos por essa convenção, não poderia ser caracterizada como norma jurídica ${ }^{10}$. Posteriormente, já no posfácio de sua citada obra, Hart concede que, para além de uma convenção social aferível no plano fático, a regra de reconhecimento também poderia assumir-se enquanto convenção moral, na medida em que o próprio sistema jurídico autorize e exija esse uso da moral ${ }^{11}$. É dizer, para além de cumprir condições de validade formais, uma norma que pretende ser jurídica poderia também necessitar cumprir condições morais de validade colocadas pela própria regra de reconhecimento. É esta exigência de cariz moral que diferenciará a regra de reconhecimento hartiana da tese das fontes sociais hoje sustentada pelo denominado positivismo jurídico exclusivo ${ }^{12}$. Shapiro ${ }^{13}$ aponta, inclusive, que por pretender se fortalecer ao exigir critérios morais de validade é que a regra de reconhecimento hartiana finda por enfraquecer-se.

Buscando não recair no equívoco experimentado por Hart, o positivismo jurídico exclusivo purificará o processo de identificação do direito de qualquer exigência moral ${ }^{14} \mathrm{e}$ o reduzirá ao seu momento de autoridade: saber se dada norma consubstancia-se em direito ou não passa a ser somente uma questão de fato ${ }^{15}$. O direito é um fato social emanado de um órgão autorizado para tanto. Será o direito um "comando, norma ou ordem produzidos por uma autoridade estatal" 16 .

O fato de a autoridade das fontes depender, em última análise, de quem a comandou, e não do conteúdo comandado ocorre porque, só assim, seria possível identificar as fontes e normas jurídicas objetivamente. A inclusão de juízos morais para a aferição da validade das

em casos concretos." DECOMAIN, Pedro Roberto; LEAL, João José. Súmula vinculante, regras de reconhecimento e textura aberta do Direito Análise à luz do pensamento de Herbert L. A. Hart Resenha Eleitoral - Nova Série, v. 11, n. 1, jan.-jun. 2004.

${ }^{10}$ HART, op. cit., p. 124

${ }^{11}$ Ibid. p. 204.

${ }^{12}$ Joseph Raz é considerado o maior artífice do positivismo jurídico exclusivo, sendo quem primeiro arquitetou a tese das fontes sociais na maneira em que ela é hoje aceita pelo citado movimento teórico. RAZ, Joseph. The Authority of Law; Ethics in the Public Domain. Oxford: Clarendon Press, 1994. Id. The Concept of a Legal System. 2 ed. Oxford: Clarendon Press, 1980.

${ }^{13}$ SHAPIRO, Scott J. The "Hart-Dworkin" debate: a short guide for the perplexed. New York: Cambridge University Press, 2007, p. 8.

14 "For them, tests of legality must always distinguish law from non-law based exclusively on their social source and must be implementable without resort to moral reasoning." Ibid., p. 19-20.

${ }^{15}$ RAZ, op. cit., 1994, p. 205-206.

${ }^{16}$ BUSTAMANTE, Teoria do Precedente Judicial: a justificação e a aplicação de regras jurisprudenciais. São Paulo: Noeses, 2012, p. 95. 
Revista Eletrônica de Direito Processual - REDP.

Rio de Janeiro. Ano 11. Volume 18. Número 1. Janeiro a Abril de 2017

Periódico Quadrimestral da Pós-Graduação Stricto Sensu em Direito Processual da UERJ

Patrono: José Carlos Barbosa Moreira. ISSN 1982-7636. pp. 377-402

www.redp.uerj.br

normas seria adentrar em terreno pedregoso, onde seria impossível atingir convenções sobre desacordos. Em veredas morais entraria em jogo a chamada incomensurabilidade conceitual, ou seja, a inexistência de "um critério compartilhado para medir a racionalidade ou irracionalidade da premissa de que parte o adversário"17. Fazer do juízo jurídico um juízo moral seria admitir a impossibilidade de uma identificação do objeto da ciência jurídica ${ }^{18}$.

Como se percebe, tanto a regra de reconhecimento quanto a tese das fontes sociais abraçam critérios formais que deverão ser necessariamente acessados para saber se uma norma é jurídica ou não. Sem o atendimento ao critério do fato social, é dizer, sem a autorização de uma prática social reconhecida pelos oficiais do direito, nenhuma norma chegará a ser norma jurídica sob qualquer das óticas positivistas descritas. A diferença principal será que a regra de reconhecimento de Hart não se satisfaz em reconhecer o direito como fato puramente social, como sustenta a tese das fontes sociais dos exclusivistas, podendo reclamar também o atendimento a critérios morais.

Com a criação desta barreira bem delimitada para o reconhecimento da validade do direito, as duas teses vinculadas ao positivismo fornecem um excelente parâmetro para distinguir cada uma das famílias jurídicas de acordo com o critério das fontes.

No civil law, a conjugação de uma doutrina clássica da separação dos poderes com o princípio da legalidade entronará o poder legislativo ao status de autoridade reconhecida como competente para criar comandos jurídicos ${ }^{19}$. O fato social reconhecido para a definição do direito é a elaboração da lei pelo Parlamento, ou seja, o direito já sairia pronto e autossuficiente do Legislativo, sendo um todo coerente, e "assim capaz de dar à jurisdição as condições de solucionar qualquer caso, o juiz jamais precisaria cristalizar uma norma para regular a situação litigiosa" ${ }^{20}$. Não existe qualquer tarefa criativa atribuível ao juiz, responsável unicamente por subsumir a norma autorizada pelo Legislativo a uma situação

\footnotetext{
${ }^{17}$ TORRANO, Bruno. Democracia e Respeito à Lei: entre o positivismo jurídico e o pós positivismo. Rio de Janeiro: Lumen Juris, 2015, p.11.

${ }^{18}$ MARANHÃO, Juliano. Positivismo jurídico lógico inclusivo. Madrid: Marcial Pons, 2012, p. 36-40.

${ }^{19}$ FON, Vincy; PARISI, Francesco. Judicial Precedents in Civil Law Systems: A Dynamic Analysis. University of Minnesota Law School Legal Studies Research Paper, n. 07-19/ George Mason University School of Law Law and Economics Research Paper No. 04-15, 2004, p. 4. Disponível em: http://ssrn.com/abstract=534504. Acesso em: 23 mar. 2016.

20 MARINONI, Luiz Guilherme. O precedente na dimensão da igualdade. 2011, p. 95. Disponívelem:<http://www.marinoni.adv.br/files_/O\%20Precedente\%20na\%20Dimens\%C3\%A3o\%20da\%2 OIgualdade.docx.>. Acesso em: 14 fev. 2016.
} 
Revista Eletrônica de Direito Processual - REDP.

Rio de Janeiro. Ano 11. Volume 18. Número 1. Janeiro a Abril de 2017

Periódico Quadrimestral da Pós-Graduação Stricto Sensu em Direito Processual da UERJ

Patrono: José Carlos Barbosa Moreira. ISSN 1982-7636. pp. 377-402

www.redp.uerj.br

fática determinada. $\mathrm{O}$ professor português Aroso Linhares ${ }^{21}$, resumindo como atuaria a jurisdição no positivismo analítico (por ele denominado normativismo), vinca que admitir uma complementação jurídica do sentido da norma diante do caso concreto seria negar a própria autossuficiência do significado normativo e, consequentemente, a autonomia do direito.

Esse tipo de positivismo aceita a existência de juízos morais subjetivos no momento de concretização das normas jurídicas, no entanto tais juízos não estariam protegidos pelo manto da juridicidade, sendo permitidos na medida de uma discricionariedade controlada exercida pelo judiciário. A discricionariedade não deveria ser fustigada, mas, sim, ser bem delimitada e controlada ${ }^{22}$.Só quando do parlamento emanasse uma regra geral atribuindo normatividade jurídica às decisões judiciais é que estas estariam autorizadas a funcionar também como fontes formais do direito 2324 .

No common law, a autoridade competente para declarar o direito seria o próprio Judiciário. Declarar o direito não implicaria, contudo, em criá-lo. Como será desenvolvido adiante, diversas teorias buscaram refletir a forma como a cultura anglo-saxã compreendia a criação de direito pelo common law. Pode-se adiantar, todavia, que esta tradição se consolida em torno de uma teoria declaratória do precedente judicial ${ }^{25}$ que concebe o Judiciário apenas como uma autoridade declaradora de uma normatividade assentada em um "corpo reconhecido de experiência comum, resultado de um processo ao qual se atribui autoridade por conta de suas relações históricas com um senso de identidade compartilhado na comunidade"26. Pela teoria declaratória, portanto, a fonte jurídica seriam os costumes.

\footnotetext{
${ }^{21}$ LINHARES, José Manuel Aroso. Introdução ao Pensamento Jurídico Contemporâneo. (Manuscritos desenvolvidos para apoio à disciplina de mesmo nome no ano 2011-2012 lecionada na Faculdade de Direito da Universidade de Coimbra). Coimbra, 2012.

22 DIMOULIS, op. cit., 2011, p. 230-231.

${ }^{236} \mathrm{Na}$ perspectiva positivista, é crucial a delimitação das competências de cada poder, levando também em consideração a hierarquia das fontes do direito. A partir do momento em que a Constituição ou a lei distribui as competências em determinado setor de atividade estatal não se justificam críticas de usurpação de competência, caso um Poder decida nesse setor no âmbito de sua competência." Ibid, p. 225.

${ }^{24}$ Um exemplo na ambiência brasileira desta delegação do parlamento ao Judiciário de uma tarefa que ser-lheia originalmente própria poderia ser o atual artigo $927^{24}$ do Novo Código de Processo Civil que, em seus incisos, indica uma série de tipos de decisões judiciais possuidoras de força jurídica. Fora do alcance concedido pela convenção social simbolizada pelo código, não haveria como se identificar como direito as decisões judiciais.

${ }^{25}$ CROSS, Rupert e HARRIS, J.W. Precedent in English Law. 4 ed., Oxford, Clarendon, 1991.

${ }^{26}$ VOJVODIC, Adriana De Moraes. Precedentes e argumentação no Supremo Tribunal Federal: entre a vinculação ao passado e a sinalização para o futuro. 2012. 260f. Tese (Doutorado em Direito). Faculdade de Direito da Universidade de São Paulo, São Paulo, p. 52.
} 
Revista Eletrônica de Direito Processual - REDP.

Rio de Janeiro. Ano 11. Volume 18. Número 1. Janeiro a Abril de 2017

Periódico Quadrimestral da Pós-Graduação Stricto Sensu em Direito Processual da UERJ

Patrono: José Carlos Barbosa Moreira. ISSN 1982-7636. pp. 377-402

www.redp.uerj.br

Vincamos ser a forma de enxergar a interação entre as diversas fontes jurídicas a partir da tese das fontes sociais ou da regra de reconhecimento equivocada por não conseguir resolver de forma satisfatória problemas práticos relacionados à aplicação do direito. Tais construções não avançam no que MacCormick diagnosticou como "problema do positivismo": diante da possibilidade de emergência de diversas normas jurídicas a partir de uma mesma fonte, o positivismo não fornece diretivas para indicar qual norma deve prevalecer $^{27}$.

É dizer, para que um discurso jurídico presente em uma decisão judicial esteja legitimado é insuficiente dizer que sua correção se baseie somente na validade da norma que o subjaz. É preciso, pois, ou ir além da validade ou reconstruir o próprio conceito de validade para que tenhamos uma categoria que de fato explique o funcionamento do sistema jurídico no seu nível aplicativo. Em outro flanco, ao afirmar que só normas reconhecidamente válidas podem gerar efeitos jurídicos, as teses positivistas acabam por fechar os olhos a diversas categorias normativas que, embora não formalmente reconhecidas, atuam de forma influente na prática jurídica como razões das decisões; princípios morais, razões pragmáticas ou mesmo finalidades de políticas públicas são mobilizadas até mesmo para superar a solução jurídica fornecida pela regra reconhecida formalmente ${ }^{28}$.

Aulis Aarnio ${ }^{29}$ realiza trabalho que aqui nos será útil ao propor um conceito de fonte válida que alia a validade formal a um horizonte argumentativo. Em sua empreitada, a validade de uma norma seria dependente de três dimensões: a sistêmica, a efetiva e a axiológica. A primeira dimensão diz respeito a sua validade formal. $\mathrm{O}$ que era um conceito quase total da validade para o positivismo passa a ser somente uma das dimensões da validade para Aarnio. A validade sistêmica verifica-se quando a norma satisfaz quatro condições, a saber: i) ter sido aceita e promulgada segundo o procedimento devido; ii) não

\footnotetext{
27 “Uma descrição positivista do sistema tal como ele opera não pode responder a um tipo particular de questão que pode ser formulada internamente em um sistema jurídico: a questão que pode ser formulada diante de um juiz, em um caso difícil, da seguinte maneira: 'Por que nós devemos tratar todas as decisões alcançadas em conformidade com uma regra válida segundo nosso critério de validade como suficientemente justificadas?', e esta é uma questão que pode, e de tempos em tempos é, levantada. Ademais, o positivismo não consegue também responder à questão formulada pelos juízes ainda mais frequentemente: 'Como nós devemos justificar as decisões concernentes à interpretação e à aplicação de nossos critérios de validade? " MACCORMICK, Neil. Legal Reasoning and Legal Theory. Oxford, Clarendon, 1978, p. 63.

${ }^{28}$ DWORKIN, Ronald. Ronald Dworkin and the contemporary jurisprudence. London: Duckworth, 1984, p. 247.

${ }^{29}$ AARNIO, Aulis. Le rationnel comme raisonnable: la justification en droit. Paris: Librairie Générale de Droit et de Jurisprudence, 1992, p. 43.
} 
Revista Eletrônica de Direito Processual - REDP.

Rio de Janeiro. Ano 11. Volume 18. Número 1. Janeiro a Abril de 2017

Periódico Quadrimestral da Pós-Graduação Stricto Sensu em Direito Processual da UERJ

Patrono: José Carlos Barbosa Moreira. ISSN 1982-7636. pp. 377-402

www.redp.uerj.br

ter sido derrogada; iii) não contradizer outra norma vigente do mesmo sistema; e, iv) se houver contradição, existir uma regra aceita para solucionar o conflito. A validade efetiva diz respeito a chamada "validade fática" da fonte, ou seja, a adesão que determinada fonte possui no seio social na medida em que é reconhecida ou não como cogente. Segundo Dobrowolski ${ }^{30}$ "Aarnio identifica esta concepção da validade com o chamado realismo jurídico" para quem "uma norma jurídica é válida, quando se encontra na ideologia normativa experimentada como vinculante pelas autoridades que decidem e aplicam o Direito". Parar aqui, contudo, também seria insuficiente, pois recair-se-ia no mesmo erro cometido pelo realismo jurídico ao reduzir a validade a um critério puramente fático, empírico. A validade axiológica, por fim, permite que analisemos se uma norma jurídica formalmente válida ou mesmo faticamente válida está adequada a um determinado sistema de valores. Esta adequação, por seu turno, terá de ser comprovada argumentativamente, podendo a argumentação inclusive acessar sistemas extrajurídicos para justificar a validade. É na validade axiológico-argumentativa que reside, pois, todo o arsenal justificatório que a teoria das fontes de Aarnio nos propicia. Ainda que uma norma sistemicamente aceita e faticamente aplicável se coloque à disposição do aplicador, deverá ele justificar sua validade axiológica argumentativamente ${ }^{31}$.

Lembremos, pois, que as três dimensões de validade para Aarnio devem ser lidas de forma cumulativa. Segundo Teixeira os problemas teóricos aparecem quando tentamos utilizar isoladamente uma das dimensões do conceito como sendo o tipo autêntico de validade $^{32}$. É esta passagem de um conceito unicamente institucional para um conceito argumentativo de validade a lente a ser aplicada para nossa análise sobre a diferença conceitual entre o common law e o civil law a respeito da validade das fontes ${ }^{33}$.

${ }^{30}$ DOBROWOLSKI, Samantha Chantal. Justificação jurídica e sociedade na visão de Aulis Aarnio. Dissertação (Mestrado). Universidade Federal de Santa Catarina (1997). Faculdade de Direito. Orientador: Leonel Severo Rocha.

${ }^{31}$ AARNIO, op. cit., p. 54.

32 TEIXEIRA, João Paulo Allain. Crise moderna e racionalidade argumentativa no direito: o modelo de Aulis Aarnio. Revista de informação legislativa, v. 39, n. 154, p. 213-227, 04/2002, p. 223.

${ }_{33}$ Adriana Vojvodic, em Tese de doutoramento defendida na Universidade de São Paulo, também expõe a falácia da proposta de se dividir de forma naturalizante fontes próprias em cada uma das tradições. Percebe-se, assim, o estabelecimento de uma dicotomia entre sistemas de common law e de civil law, que, por reconhecer diferentes fontes básicas do direito, acabam por diferir no modo como o direito como um todo é compreendido e aplicado, gerando métodos de raciocínio legal diferenciados. Essa compreensão da relação entre os sistemas jurídicos, que é compartilhada por diversos autores nacionais e estrangeiros, deixa de levar em conta, porém, o fato de que compreender o precedente unicamente a partir da lógica das fontes do direito retira seu peso 
Revista Eletrônica de Direito Processual - REDP.

Rio de Janeiro. Ano 11. Volume 18. Número 1. Janeiro a Abril de 2017

Periódico Quadrimestral da Pós-Graduação Stricto Sensu em Direito Processual da UERJ

Patrono: José Carlos Barbosa Moreira. ISSN 1982-7636. pp. 377-402

www.redp.uerj.br

Nas conclusões do já referenciado trabalho, Neil MacCormick e Robert Summers ${ }^{34}$ apontam que uma das similaridades entre as tradições de common law e civil law é que precedentes importam de forma significativa em jurisdições de ambas as tradições, independentemente de reconhecimento destes enquanto formalmente vinculantes. Para os autores, até mesmo para compreender sistemas jurídicos que formalmente não preveem o uso de precedentes como parâmetro decisório (o caso francês é pinçado como exemplo) seria incontornável levar em consideração a força normativa que tal categoria representa para a prática jurídica cotidiana. $\mathrm{O}$ tema das fontes jurídicas não pode, pois, ser tratado de forma dicotômica, como se estivéssemos entre o tudo ou nada, entre as fontes da common law e as fontes da civil law, mas, sim, enxergado como um processo contínuo, em que distintas fontes encontram-se em interação permanente e não exclusiva. A concretização do direito não é uma escolha entre aplicar leis ou precedentes, já que as duas fontes sempre trabalharão conjuntamente ${ }^{35}$.

Sobre a pretensão do monopólio do sentido do direito em cada uma das famílias, Marinoni expressamente adverte não existir diferença em termos de validade entre decisões judiciais e legislação em cada uma das tradições. A diferença está, isto sim, na teoria que subjaz à compreensão de cada uma destas categorias normativas ${ }^{36}$. Tal conclusão é corroborada por Bustamante, para quem a diferença entre common law e civil law não é outra coisa senão uma imagem falsa forjada pelo modo de pensar positivista ${ }^{37}$. Recusada a tese da fonte social positivista, a distinção no âmbito da validade puramente sistêmica que era realizada entre as normas de common law e civil law passa a ter baixíssima utilidade prática. Qual a função de se perguntar qual norma é formalmente aceita como válida por uma determinada fonte se tal resposta não é suficiente para responder problemas jurídicos concretos?

\footnotetext{
argumentativo por tratá-lo como um elemento meramente auxiliar na tomada de decisão, mitigando assim a importância do precedente judicial na argumentação da corte. VOJVODIC, op. cit., p. 65.

${ }^{34}$ MACCORMICK; SUMMERS, op. cit., 1997, p. 530.

${ }^{35}$ VERESHCHAGIN, Alexander. Judicial Law-Making in Post-Soviet Russia Abingdon/UK: RoutledgeCavendish, 2007, p. 113; SOUZA, Op. cit., 2013, p. 12

36 "Nunca se pensou em negar ao juiz do common law o poder de interpretar a lei. De modo que, se alguma diferença há, no que diz respeito aos Códigos, entre o civil law e o common law, tal distinção está no valor ou na ideologia subjacente à ideia de Código". MARINONI, Luiz Guilherme. Aproximação crítica entre as jurisdições de civil Law e de common law e a necessidade de respeito aos Precedentes no brasil. Revista da Faculdade de Direito - UFPR, Curitiba, n.47, p.29-64, 2008, p. 30.

${ }^{37}$ BUSTAMANTE, op. cit., 2012, p. 95.
} 
Revista Eletrônica de Direito Processual - REDP.

Rio de Janeiro. Ano 11. Volume 18. Número 1. Janeiro a Abril de 2017

Periódico Quadrimestral da Pós-Graduação Stricto Sensu em Direito Processual da UERJ

Patrono: José Carlos Barbosa Moreira. ISSN 1982-7636. pp. 377-402

www.redp.uerj.br

\subsection{A equivalência do papel dos juízes nas diferentes tradições jurídicas}

Sociedades contemporâneas admitem um modelo no qual inexiste um chanceler único da normatividade geral - seja o Judiciário, seja o Legislativo, podendo o direito ser encontrado na construção argumentativa que o Judiciário faz de princípios constitucionais ${ }^{38}$. Assim, um outro flanco a erodir as bases da distinção entre os sistemas jurídicos no âmbito conceitual é a admissão de que o Judiciário, necessariamente, cria direito. Marcelo Alves de Souza $^{39}$ vinca ser falsa a tese de que o juiz vinculado à tradição do common law tem um papel diferente daquele vinculado às tradições civilistas. Ambos, na visão de Souza, criam direito. Esse não estará já pronto e acabado nos Códigos ou já totalmente à disposição da sociedade para ser declarado por decisões judiciais, mas, sim, possuirá uma dimensão só desvelada no momento de sua aplicação pelo Judiciário.

Scalia $^{40}$ diagnostica que, quando a comunidade jurídica anglo-saxã percebe o acerto do argumento trazido pelo movimento realista de que os Juízes, de fato, criavam direito, surge um desconforto na relação entre o common law e a democracia, uma vez que esta última possuiria como pressuposto incontornável uma visão estanque da separação de poderes. O desenho institucional do Judiciário no common law explicita a inviabilidade da explicação positivista para a aplicação jurídica, desvelando que o direito só tem sua produção concluída no momento da decisão judicial. Torna-se simplório e reducionista criticar a produção de direito pelo Judiciário como um plano para dotar tal poder de competência legislativa ou executiva ${ }^{41}$. $\mathrm{O}$ fato de ser reconhecida a natureza normogênica da atividade

\footnotetext{
${ }^{38}$ Ibid. p. 31-38.

${ }^{39}$ SOUZA, Marcelo Alves Dias de. The Brazilian Model of Precedents: a New Hybrid between Civil and Common law. Thesis submitted for the degree of Doctor of Philosophy King's College London - KCL The Dickson Poon School of Law. 2013, p. 13.

${ }^{40}$ SCALIA, Antonin. Common-Law Courts in a Civil-Law System: The Role of United States Federal Courts. Interpreting the Constitution and Laws. The Tanner Lectures on Human Value. Princeton University, 1995 , p. 86.

${ }^{41}$ O processualista Nelson Nery Júnior critica o Código de Processo Civil de 2016 em razão de o diploma estabelecer uma suposta prioridade hierárquica da jurisprudência frente às demais leis e à Constituição. Esta modificação só seria possível por Emenda Constitucional: “[De acordo como o novo CPC] a jurisprudência vincula, mas a Constituição e a lei, não. Colocaram no novo código algo que deveria ser determinado por emenda constitucional. (...) As medidas do novo CPC tendentes a dar poderes legislativos aos tribunais são inconstitucionais. Mas nenhum tribunal vai dizer que são. Vendo uma barbaridade dessas, um passa-moleque desses na sociedade brasileira, eu, como jurista, não posso deixar de falar que isso é inconstitucional." NERY JÚNIOR, Nelson. Nery Jr. critica norma do novo CPC que obriga juiz a observar jurisprudência. Revista Consultor Jurídico. Disponível em: <http://www.conjur.com.br/2015-jul-02/nery-jr-critica-norma-obrigajuiz-observar-jurisprudencia>. Acesso em: 12 dez. 2015.
} 
Revista Eletrônica de Direito Processual - REDP.

Rio de Janeiro. Ano 11. Volume 18. Número 1. Janeiro a Abril de 2017

Periódico Quadrimestral da Pós-Graduação Stricto Sensu em Direito Processual da UERJ

Patrono: José Carlos Barbosa Moreira. ISSN 1982-7636. pp. 377-402

www.redp.uerj.br

judicial não implica em dizer que a jurisprudência passará a eclipsar a intensidade normativa das leis e das constituições, mas, sim, que não haveria direito "acabado" e, portanto, razões disponíveis antes que o caso jurídico fosse iniciado ${ }^{42}$.

A linha de chegada nas duas tradições jurídicas demonstra que o debate deixa de pretender responder à questão sobre a atividade criativa do juiz para passar a questionar de que forma tal atividade pode ser controlada ${ }^{43}$. Ingressamos em um contexto caracterizado pela concorrência de normatividades, em que normas sem reconhecimento jurídico formal disputam com normas reconhecidas formalmente a sua utilização como parâmetro para a solução de casos. Nesta quadra, inegável que diferenciar sistemas de tradições diferentes com base nas suas fontes jurídicas será impor uma falsa distância entre eles. Necessário perguntar, contudo, se sobra alguma diferença em termos conceituais entre as duas tradições.

Bustamante $^{44}$, sugere que a diferença possa estar nas características da produção legislativa de cada tradição. Enquanto no sistema romano-germânico a atuação do Legislativo pretenderia ordenar o direito de forma sistemática, coerente, antecipada e englobando todos os ramos jurídicos, o legislador anglo-saxão estaria inserto em um exercício fragmentário, assistemático e voltado preponderantemente para as matérias privadas. Essa aposta, sem dúvidas, precisará confrontar, até mesmo em termos empíricos, elementos da já mencionada Tese da Convergência indicativos de que a common law atravessa não só um processo de produção legislativa fragmentada, mas também um processo de codificação ${ }^{45}$. Além disso, ainda que a age of statutes não se prove uma age of codes, importa investigar quais implicações as diferentes formas de legislar trariam para interpretação e aplicação do direito, vez que há teses fortes sustentadoras de que a interpretação de leis fragmentadas não difere da intepretação de códigos ${ }^{46}$.

\footnotetext{
${ }^{42}$ POSTEMA, Gerald J. Philosophy of the Common Law. In: The Oxford Hanbook of Jurisprudence and Philosophy of Law. COLEMAN, J.; SHAPIRO, S. (Org). Oxford: Oxford University Press, 2002.

${ }^{43}$ KOMAREK, op. cit., p. 21.

${ }^{44}$ BUSTAMANTE, op. cit., 2012, p. 115.

45 "This approach, however, evolved from an age where statutes were of marginal importance. Today it is, to a large extent, no longer tenable. This is due to the abovementioned increase in codification in countries such as Australia, the United Kingdom and the United States. This development of statutes as a source of law in Common Law jurisdictions justifies and in some areas even requires the use of statutory analogies in order to fill gaps.”, FUNKEN, Katja. The Best of Both Worlds - The Trend Towards Convergence of the Civil Law and the Common Law System. 2013. Disponível em: $<$ SSRN: http://ssrn.com/abstract=476461 orhttp://dx.doi.org/10.2139/ssrn.476461. Acesso em: 01 mar. 2016., p. 10.

${ }^{46}$ TARRANT, S. Building Bridges in Australian Criminal Law: Codification and the Common Law, Monash University Law Review, n.39, v.3 p.838-63, p. 860-862.
} 
Revista Eletrônica de Direito Processual - REDP.

Rio de Janeiro. Ano 11. Volume 18. Número 1. Janeiro a Abril de 2017

Periódico Quadrimestral da Pós-Graduação Stricto Sensu em Direito Processual da UERJ

Patrono: José Carlos Barbosa Moreira. ISSN 1982-7636. pp. 377-402

www.redp.uerj.br

Para Souza ${ }^{47}$ a diferença será que no civil law a fonte de "primeira hora" será a

legislação, enquanto no common law, o precedente. Estefânia Barboza singra no mesmo caminho, afirmando existir uma preponderância de uma forma normativa sobre a outra, a depender da tradição jurídica. ${ }^{48}$ Mas o que significaria ser fonte de primeira ou de segunda hora? Haveria uma hierarquia abstrata entre as fontes, a depender do sistema jurídico em que se encontrem? Por ter como traço incontornável de sua teoria do direito o elemento da hierarquização normativa, acreditamos que Hans Kelsen pode nos auxiliar a investigar esta questão.

\subsection{Diferenças na hierarquia entre fontes de validade argumentativa reconhecidas}

Antes de expormos a construção de Hans Kelsen, necessário apontar que sua arquitetura do sistema jurídico é uma criação de teor eminentemente analítico e descritivo, sendo sua teoria fértil para propiciar uma explicação sobre a natureza e a relação dos atos de criação do direito pelo legislador e pela jurisdição. Com base na teoria da gradação escalonada do direito de Adolf Merk ${ }^{49}{ }^{4}$, Kelsen descreve o ato jurídico como um momento de produção dupla face, onde tanto se aplica como se cria o direito. A legislação comum não seria apenas simples aplicação/execução da Constituição, também condicionando a produção/criação de outros atos normativos (atos administrativos e sentenças, por exemplo).

\footnotetext{
47 SOUZA, op. cit., p. 65.

48 "Dizer que o direito inglês é predominantemente Judiciário significa dizer que a fonte primária do seu direito são as decisões judiciais, sendo de extrema importância o papel criador de seus juízes (judge-made-law), dando-se reconhecimento à autoridade de seus precedentes. Destarte, a legal rule no direito inglês não se confunde com a regra do direito nos sistemas de civil law. O statute law tem função apenas complementar, porque pressupõe a existência dos princípios gerais criados pela jurisprudência, ou seja, as leis só possuem sentido em relação ao common law, não de forma autônoma”. BARBOZA, Estefânia Maria de Queiroz. Stare decisis, Integridade e Segurança Jurídica:Reflexões Críticas a Partir da Aproximação dos Sistemas de Common Law e Civil Law na Sociedade Contemporânea. Tese de Doutorado. Doutorado em Direito. Pontifícia Universidade Católica do Paraná. 2011, p. 33.

49 “Ao contrário do que propala o senso comum teórico dos juristas, a teoria da gradação escalonada do sistema jurídico não foi concebida originalmente por Kelsen, mas por Adolf Merkl, sendo pelo mestre austríaco instrumentalizada para a elaboração de seu conceito de direito presente na sua Teoria Pura do Direito. Foi apenas sob a reconhecida influência da Teoria da Gradação Escalonada do Direito (Stufentheorie), de seu famoso discípulo, Adolf Merkl, que Kelsen assimilaria definitivamente em sua Teoria Pura a análise da dinâmica da ordem jurídica. A influência da Stufentheorie de Merkl foi expressamente reconhecida no prefácio da segunda edição (não modificada) dos 'Problemas Capitais', em 1923, em que, lembra ainda Robert Walter, Kelsen expressamente reconhece que havia 'tomado a teoria do escalonamento como uma parte essencial no sistema da Teoria Pura do Direito"” GUEDES, Neviton de Oliveira Batista. Por que dizem que ato normativo tem duas caras? Revista Eletrônica Conjur. Disponível em: <http://www.conjur.com.br/2015fev-03/constituicao-poder-dizem-ato-normativo-duas-caras/>. Acesso em 10 mar 2015.
} 
Revista Eletrônica de Direito Processual - REDP.

Rio de Janeiro. Ano 11. Volume 18. Número 1. Janeiro a Abril de 2017

Periódico Quadrimestral da Pós-Graduação Stricto Sensu em Direito Processual da UERJ

Patrono: José Carlos Barbosa Moreira. ISSN 1982-7636. pp. 377-402

www.redp.uerj.br

As decisões judiciais, concretizadoras das leis ordinárias, e as próprias leis ordinárias, densificadoras da Constituição, são atos jurídicos que, simultaneamente, criam e aplicam (executam) normas jurídicas. A elaboração kelseniana afirma que a norma superior determinará não só a forma de produção, mas também o conteúdo da norma inferior. Tais determinações, contudo, nunca são completas, permanecendo sempre um espaço para o atuar discricionário dos aplicadores. O sistema jurídico possuiria, pois, uma dimensão dinâmica, ou seja, seria o regulador de sua própria criação ${ }^{50}$.

Aqui, lança-se mão da conhecida metáfora da moldura para vincar que "é conforme ao direito todo ato que se mantenha dentro deste quadro ou moldura, que preencha esta moldura em qualquer sentido possível" ${ }^{\text {"51 }}$. Na produção da sentença, última etapa do processo de produção/aplicação do direito, não seria uma pergunta da teoria do direito positivista de Kelsen quais, dentre as várias interpretações possíveis de uma norma, é mais correta. Podendo tal escolha basear-se em critérios não jurídicos, esta indagação estaria no âmbito de uma política do direito, mas não da teoria pura do direito. O jurista austríaco concede ao Judiciário, pois, um espaço (a moldura) de discricionariedade em que não haveria norma superior a lhe dizer qual norma mobilizar para produzir sua sentença.

A construção teórica de Kelsen possibilita vincar duas conclusões: a primeira corrobora a tese da inexistência de uma diferença de natureza entre a atividade do legislador e a atividade do juiz, já que ambos produzem direito; a segunda, enceta uma diferença em termos de grau de discricionariedade para a criação do direito entre ambas as instâncias. Esta diferença, contudo, terá igual configuração em todas as latitudes jurídicas, independentemente da tradição. A pretensão de Kelsen, essencial notar, é a de erigir uma teoria geral do direito, não uma teoria voltada para sistemas jurídicos com características específicas. A dinâmica normativa por ele desenhada apresentar-se-ia da mesma forma em qualquer das famílias jurídicas estudadas.

Aqui, embora a construção kelseniana se utilize da imagem escalonada da hierarquia entre lei (nível do legislativo) e decisão (nível do judiciário), preferimos apresentar a interação com uma imagem circular. Explicamos. Acreditamos que a própria moldura encetada pelo Legislativo tem seu tamanho e dimensões definidos também na atividade

\footnotetext{
${ }^{50}$ BUSTAMANTE, Thomas. A criação do direito pela jurisprudência: notas sobre a aplicação do direito e a epistemologia na teoria pura do direito. Revista da Faculdade de Direito de Uberlândia. v. 38 - n.2: 685 706, 2010, p. 688.

${ }^{51}$ KELSEN, Hans. Jurisdição Constitucional. São Paulo: Martins Fontes, 2003, p. 390.
} 
Revista Eletrônica de Direito Processual - REDP.

Rio de Janeiro. Ano 11. Volume 18. Número 1. Janeiro a Abril de 2017

Periódico Quadrimestral da Pós-Graduação Stricto Sensu em Direito Processual da UERJ

Patrono: José Carlos Barbosa Moreira. ISSN 1982-7636. pp. 377-402

www.redp.uerj.br

interpretativa do Judiciário. Esta caracterização circular funda-se na compreensão do direito enquanto prática hermenêutica. É dizer, a moldura já não se encontra pronta e acabada após sair do parlamento, mas, sim, será burilada pormenorizadamente pela própria jurisdição no exercício de aplicação da norma. Esta imagem circular pode ser aplicada não só na relação entre lei e decisão judicial, mas também na interação entre decisão a ser tomada e decisões anteriores, ou seja, no âmbito dos precedentes ${ }^{52}$. Assim como as leis, precedentes são peças normativas que precisam ser interpretadas. Conceder normatividade a precedentes é afirmar que os juízes que decidirão casos vindouros encontram-se constrangidos pelas interpretações e significados tomados pelos juízes anteriores. O material precedental funcionará também como um diminuidor do grau de discricionariedade da criação do direito pelo Judiciário e estará, assim como a legislação, disponível para ser construído e reconstruído enquanto moldura interpretativa.

Deve-se ajuntar, contudo, que embora o reconhecimento da força normativa dos precedentes judiciais, de fato, implique em uma mudança na relação entre os poderes estatais, sendo concedido ao Judiciário uma função antes só atribuível ao Legislativo, tal reconfiguração não implica em um cenário de preponderância de um poder sobre o outro. A relação circular entre decisão judicial e atividade legislativa garante uma distribuição equilibrada e controlável dos poderes estatais.

Percebe-se, pois, não vicejar a tese de que haveria níveis hierárquicos entre as fontes do direito a depender da tradição jurídica em que se repousem. Existe, em ambas, uma necessária relação circular, contínua e complementar entre o direito produzido pelo legislativo e o direito produzido pelo judiciário. Seja no âmbito da validade, seja no âmbito da hierarquia, os sistemas de civil law e common law estão assemelhados conceitualmente em relação às fontes que os compõem.

\footnotetext{
52 “Cada vez que um juiz, um tribunal ou qualquer outra autoridade competente para aplicar o direito define conceitos ou estabelece o sentido concreto dessa norma e, portanto, concretiza a moldura deste juiz, tribunal ou autoridade está criando com esse ato uma regra constitutiva que 'cria ou define novas formas de comportamento' relevantes para o direito. Uma norma constitutiva estabelece o sentido que um determinado ato ou fato tem no discurso do falante. No discurso jurídico, se este falante é uma autoridade que pratica atos de fala para determinar o status jurídico de algo, essas definições ou regras constitutivas obviamente têm, também, um significado normativo, pois elas são imprescindíveis para conhecer o "sentido objetivo" do ato de fala realizado pelo juiz ao solucionar uma disputa jurídica. Mesmo quando os juízes não estabelecem qualquer norma jurídica geral, não pode haver dúvida de que criam normas individuais e põem em movimento o processo dinâmico de produção do direito.” BUSTAMANTE, op. cit., 2010, p. 703-704.
} 
Revista Eletrônica de Direito Processual - REDP.

Rio de Janeiro. Ano 11. Volume 18. Número 1. Janeiro a Abril de 2017

Periódico Quadrimestral da Pós-Graduação Stricto Sensu em Direito Processual da UERJ

Patrono: José Carlos Barbosa Moreira. ISSN 1982-7636. pp. 377-402

www.redp.uerj.br

Após a desconstrução da tese da fonte social positivista nos apontar a insuficiência

do reconhecimento formal de uma norma para que ela opere como norma jurídica e depois da construção kelseniana nos servir de estro para desbotar qualquer intenção de hierarquizar fontes válidas de acordo com a tradição em que navega, devemos nos perguntar se seria a forma, a metodologia como cada fonte jurídica é aplicada o ponto a diferenciar os sistemas jurídicos de common law e civil law.

\section{APROXIMAÇÕES E DISTANCIAMENTOS NO HORIZONTE METODOLÓGICO DA INTERPRETAÇÃO/APLICAÇÃO DO DIREITO}

Determinadas teses entusiastas de uma diferença metodológica na aplicação do direito entre a common law e a civil law apontam haver formas de raciocínio diversas para cada família. A common law seria caracterizada por um raciocínio indutivo, que parte do caso para construir o princípio jurídico aplicável; a tradição continental acolheria uma forma de raciocínio dedutivo, aplicando um princípio já exposto na legislação no caso concreto ${ }^{53}$. Fairgrieve e Muir Watt ${ }^{54}$ sustentam possuir esta distinção um caráter eminentemente epistemológico, pelo qual se opõe o silogismo da tradição francesa à metodologia indutiva da tradição anglo-saxã.".

De se apontar que a oposição de tais métodos de raciocínio não seria algo que remanesceria nas funções cerebrais do aplicador sem que fosse possível acessarmos ou percebermos, como observadores externos, qual método foi utilizado na resolução do caso. A oposição implicaria em assimetrias na própria forma de justificação externa das decisões

\footnotetext{
53 "Em todo caso, o fato histórico de que common lawyers foram criados em uma dieta de case law teve um profundo efeito no nosso método judicial. Common lawyers tendem a proceder por analogia, movendo gradativamente de caso para caso. Nós tendemos a evitar generalizações grandes e abstratas, preferindo formulações limitadas e temporárias, princípios gradativamente emergindo de casos concretos conforme eles são decididos. Em outras palavras, tendemos a raciocinar de baixo para cima, a partir dos fatos dos casos que se encontram na nossa frente, enquanto nossos colegas continentais tendem a raciocinar de cima para baixo, a partir de princípios abstratos incorporados em um código. O resultado é que nós tendemos a pensar em cada caso como tendo um efeito relativamente limitado, uma base para futuras operações enquanto o direito se desenvolve avançando de caso em caso - e ocasionalmente voltando atrás se formos modestos o suficiente para reconhecer que talvez eles tenham ido longe demais". LORD GOFF OF CHIEVELEY, The Future of the common law. International and Comparative Law Quarterly, v. 46, 1997, p. 745-760, p. 753

${ }^{54}$ FAIRGRIEVE, Duncan; MUIR WATT, Horatia. Common law et Tradition civiliste. Pris. Presses. Universitaires de France/ PUF. 2006, p. 24.
} 
Revista Eletrônica de Direito Processual - REDP.

Rio de Janeiro. Ano 11. Volume 18. Número 1. Janeiro a Abril de 2017

Periódico Quadrimestral da Pós-Graduação Stricto Sensu em Direito Processual da UERJ

Patrono: José Carlos Barbosa Moreira. ISSN 1982-7636. pp. 377-402

www.redp.uerj.br

judiciais ${ }^{55}$. Enquanto a justificação na civil law passaria por um processo subsuntivo, de aplicação de regras ao caso, as decisões no common law seriam justificadas por meio da analogia, em que se estabeleceria a relação de similaridade fática entre um caso precedente e um caso vindouro.

Deste modo, mesmo após aplicado o filtro da tese da convergência, divergências metodológicas de duas ordens remanesceriam entre as duas tradições jurídicas. A primeira fundar-se-ia na diferença do método raciocínio pelo que se construiria a resposta jurídica, cristalizando-se no binômio dedutivo/indutivo, enquanto a segunda derivaria da forma de justificação das decisões, dividindo-se as tradições entre a subsunção e analogia.

Para responder e testar tais hipótese de diferenças metodológicas, valeremo-nos da contribuição desenvolvida por Thomas Bustamante ${ }^{56}$ ao investigar se o precedente judicial poderia ser aplicado de forma idêntica tanto na tradição anglo-saxã quanto na romanogermânica. Assim, malgrado a investigação de Bustamante ter um objeto mais reduzido e particular - interpretação e aplicação de precedentes-, acreditamos que parte de seus referenciais podem ser utilizados para responder ao questionamento mais amplo de saber se, em termos gerais, pode-se afirmar que as bases metodológicas para a aplicação do direito como um todo variam de acordo com a tradição escolhida.

Dois argumentos construídos por Bustamante pretendem solapar a tese da autonomia metodológica das tradições jurídicas.

O primeiro repousa no valor assumido pelo princípio da universalidade no pensamento jurídico contemporâneo; o segundo expõe a relação pendular do direito, sempre se movendo entre a autoridade e a racionalidade. Para melhor compreender ambos argumentos devemos nos deter sobre a segunda das características com que predicamos o

\footnotetext{
55 "From the point of view of modern hermeneutics, the notions of understanding, interpreting and applying an object, in our case a norm, are seen as "an integral part of the hermeneutical process." 46 Nevertheless, from the analytical point of view we can distinguish the "psychological process of judicial decision-making" and the "justification" of a legal decision, 47 which can be studied separately for the purposes of the construction of legal knowledge and evaluation of legal arguments. Hence, although at the hermeneutical level it may be true that the activities of interpretation and application of law are inseparable, these steps should be neatly differenced for the purpose of the analysis of the justification of legal judgments." BUSTAMANTE, Thomas da Rosa de. Finding Analogies between Cases: On Robert Alexys Third Basic Operation in the Application of Law. In: BUSTAMANTE, T.R; PULIDO, C., B.(Org.). On the Philosophy of Precedent - Proceedings of the 24th World Congress of the International Association for Philosophy of Law and Social Philosophy, v. 3 - ARCHIV FUR RECHTS-UND SOZIALPHILOSOPHIE, BEIHEFT 133. 01ed.Stuttgart: Franz Steiner Verlag, p. 59-71, 2012b, p.10-11.

56 BUSTAMANTE, op. cit., 2012a, p. 93-123.
} 
Revista Eletrônica de Direito Processual - REDP.

Rio de Janeiro. Ano 11. Volume 18. Número 1. Janeiro a Abril de 2017

Periódico Quadrimestral da Pós-Graduação Stricto Sensu em Direito Processual da UERJ

Patrono: José Carlos Barbosa Moreira. ISSN 1982-7636. pp. 377-402

www.redp.uerj.br

positivismo contemporâneo no tópico anterior e que agora merece ser aprofundada: a separação entre o direito e a moral.

Para o positivismo exclusivo contemporâneo, o ideal de autonomia do direito possibilita que as normas jurídicas tenham validade independentemente dos seus conteúdos. Não há, pois, como vincular a juridicidade a determinadas linhas morais de decisão. Tal configuração teórica segue a linha de uma teoria analítica (não normativa) do direito, preocupada em descrever o fenômeno jurídico e responder à pergunta "o que é direito?", sem que a resposta para tal indagação necessite passar por testes valorativos. Neste ponto, importante diferenciar o sentido que se quer dar à distinção entre as compreensões analíticas e normativas do direito.

Pode-se dizer que as compreensões analíticas ou descritivas enxergam o direito sob o ponto de vista do intérprete/ observador. Para este a pergunta fundamental será “o que é o direito? ". Respondendo satisfatoriamente esse questionamento é que lhe será possibilitado, após a identificação exata do que seria o direito, tomar a decisão diante de um caso concreto $^{57}$. No plano das propostas analíticas, não é prioritário adotar referenciais de correção para o fenômeno jurídico, ou seja, não importa se o que foi descoberto como direito é justo, correto ou proporcional.

As compreensões normativas, por seu turno, tentam reunir formas de compreensão do direito para as quais é importante que o fenômeno jurídico possua em sua natureza padrões de correção. O direito é enxergado sobre uma perspectiva ideal. É dizer, a pergunta capital às perspectivas normativas seria “o que deve ser o direito?" e não simplesmente o que ele é. Adotam tais formulações a perspectiva não do observador, mas do participante, pois serão os próprios atores do cenário jurídico, mormente aqueles que aplicarão o direito, os responsáveis por empreender a tarefa correcional. Daí a denominação de normativas, pois direcionadoras do sentido que o direito deve ter.

Ironicamente, as bases para o florescimento das teorias normativas têm seu gérmen em uma das formulações de um dos principais positivistas do século XX, Herbert Hart. Quando o próprio positivismo de bases hartianas admite a existência de um ponto de vista interno do direito ${ }^{58}$, a teoria jurídica se apercebe que o direito não consiste em um objeto

\footnotetext{
${ }^{57}$ MARANHÃO, op., cit., p. 64-65.

${ }^{58}$ Devemos lembrar que a regra de reconhecimento propriamente dita pode ser visualizada de dois pontos de vista: um é expresso por meio de um enunciado de fato externo, segundo o qual a regra existe na prática efetiva
} 
Revista Eletrônica de Direito Processual - REDP.

Rio de Janeiro. Ano 11. Volume 18. Número 1. Janeiro a Abril de 2017

Periódico Quadrimestral da Pós-Graduação Stricto Sensu em Direito Processual da UERJ

Patrono: José Carlos Barbosa Moreira. ISSN 1982-7636. pp. 377-402

www.redp.uerj.br

estático, compreensível somente analiticamente por um referencial externo, mas, sim, que é também construído pelos participantes do cenário jurídico "através de uma prática social em que vão sendo paulatinamente sedimentados os conteúdos de regulação normativa compostos pelas regras jurídicas e suas respectivas intepretações" ${ }^{\text {"59 }}$. O direito é, assim, também construído por dentro de sua prática, estando seu significado em permanente disputa no cenário aplicativo. É justamente esta guinada para a perspectiva interna, denominada "virada hartiana", que propiciará as bases para que vicejem teorias argumentativas do direito que racionalizam a inserção de discursos morais em discursos jurídicos.

A prática jurídica passa a ser enxergada como prática argumentativa na qual os participantes desenvolvem uma série de pretensões normativas sobre os significados das disposições legais e precedentais. As formas e modos de argumentar sobre proposições normativas passam a ser um tema caríssimo à teoria do direito ${ }^{60}$, pois a autoridade não será um elemento prévio e conquistado, mas, sim, um algo constituído pela própria interpretação à qual o fenômeno jurídico se subordina. Encarar o direito sob o aspecto interpretativo não significa apenas dizer que o direito passa a ser o resultado da interpretação, dando-lhe um sentido de produto já acabado pelo intérprete, mas também abrir o fenômeno jurídico para o devir da interpretação futura, dos novos ciclos interpretativos ${ }^{61}$. Os aplicadores do direito passam a estar engajados em um mesmo tipo de raciocínio, qual seja, impor a melhor interpretação da prática em que se encontram ${ }^{62}$.

A pergunta "o que é o direito?" passa a ser incindível da pergunta "o que deve ser o direito?", ou "como interpreto o direito?", pois atribui-se ao direito um caráter inegavelmente ideal, em que o dever jurídico de decidir é sinônimo de decidir corretamente $^{63}$. Em todos os atos de produção e aplicação do direito existe uma pretensão implícita de que se trata de um ato correto. Na medida em que todos os sistemas jurídicos necessariamente possuem tal pretensão de correção, há uma conexão necessária entre direito

\footnotetext{
do sistema; o outro é expresso por meio dos enunciados de validade internos feitos por aqueles que a usam para identificar o direito.

${ }^{59}$ BUSTAMANTE, op. cit., 2012a, p. 130.

${ }^{60}$ DWORKIN, op. cit., 1986, p. 13.

${ }^{61}$ BUSTAMANTE, op. cit. 2015, p. 307-327.

${ }^{62}$ MARMOR, Andrei. Prefácio. In: MARMOR, Andrei (Org). Direito e Interpretação. São Paulo: Martins Fontes, 2000, p. 4-8. p. 4.

${ }^{63}$ ALEXY, Robert. Derecho y Correccíon: La Institucionalización de la Justicia, Granada: Comares, 2005, p. 46.
} 
Revista Eletrônica de Direito Processual - REDP.

Rio de Janeiro. Ano 11. Volume 18. Número 1. Janeiro a Abril de 2017

Periódico Quadrimestral da Pós-Graduação Stricto Sensu em Direito Processual da UERJ

Patrono: José Carlos Barbosa Moreira. ISSN 1982-7636. pp. 377-402

www.redp.uerj.br

e moral. Nesta construção, uma norma juridicamente válida e moralmente inaceitável não consubstancia somente um defeito moral, mas também um defeito jurídico ${ }^{64}$.

Nessa nova fronteira, o positivismo seria um instrumental teórico insuficiente para compreender a dinâmica jurídica como prática social, na medida em que, conforme já pincelado na seção anterior, as disputas argumentativas sobre os significados normativos sequer existem na formulação positivista. Os únicos desacordos que as lentes positivistas possibilitariam enxergar seriam os desacordos sobre a validade ou não das normas, não caracterizados como argumentativos.

Nossa intenção com esta breve digressão aos argumentos das correntes póspositivistas sobre a conexão entre direito e moral é esboçar o cenário teórico em que Bustamante desenvolverá seus argumentos sobre a ausência de autonomia entre a aplicação do precedente na common law e no civil law.

Voltando ao primeiro argumento de Bustamante, o valor que o princípio da universalização assumirá no direito contemporâneo significará que, ao aplicar o direito a um problema, estamos nos comprometendo com uma proposição argumentativa universal, ou seja, com uma resposta que pretende ser, além de jurídica, acertada, correta. A universalidade da regra utilizada para solucionar o caso seria um atributo indispensável para a justificação da solução dada, sendo juridicamente impossível "justificar qualquer decisão, ou qualquer regra inferida de uma decisão, senão por enunciados universais" ${ }^{65}$. Esta correspondência entre universalização e justificação é uma constante em qualquer sistema jurídico ${ }^{66}$.

A empreitada teórica de Bustamante dissolve tanto o binômio relativo a um suposto método de raciocínio próprio de cada tradição jurídica - dedução vs. indução - quanto o binômio relacionado a forma de justificação das decisões - analogia vs. subsunção.

A indução e a dedução serão formas de raciocínio instrumentalizadas em ambas as tradições para operacionalizar a universalização de argumentos, sendo interpretados

\footnotetext{
${ }^{64}$ Ibidem, p. 138.

${ }^{65}$ BUSTAMANTE, op. cit., 2012a, p. 12.

66 “Em qualquer sistema jurídico, um precedente judicial só poderá constituir um padrão para resolver casos futuros caso seja possível dele extrair uma regra universal à qual os casos futuros possam e devam ser submetidos sempre que se repetirem as condições presentes na hipótese de incidência. (...) Qualquer que seja o poder normativo dos juízes, ele só pode ser legitimamente exercido se na argumentação que justifica cada decisão puder ser construída em uma linguagem universal, imparcial, construída por meio de regras. Dizer que há raciocínio indutivo no common law é tão implausível quanto dizer que há uma contraposição entre razão e experiência - como se fosse possível aprender qualquer coisa com a nossa experiência senão através do uso de nossa racionalidade para formular hipóteses e padrões de reprodutibilidade - como fazia o Realismo Jurídico mais radical." Ibid. p. 113- 114.
} 
Revista Eletrônica de Direito Processual - REDP.

Rio de Janeiro. Ano 11. Volume 18. Número 1. Janeiro a Abril de 2017

Periódico Quadrimestral da Pós-Graduação Stricto Sensu em Direito Processual da UERJ

Patrono: José Carlos Barbosa Moreira. ISSN 1982-7636. pp. 377-402

www.redp.uerj.br

metodologicamente da mesma maneira nos dois sistemas e a eles podendo ser atribuídos os mais diferentes papéis ${ }^{67}$.

A reinvenção da justificação por analogia, por sua vez, é explicada com o transporte da diferenciação entre regra e princípio realizada por Alexy ao palco da intepretação e aplicação de precedentes. Alexy ${ }^{68}$ compreende haver uma diferença qualitativa entre regra $\mathrm{e}$ princípio. Aquela seria caracterizada como razão definitiva, enquanto esse seria uma razão prima facie. Neste contexto, princípios serão mandados de otimização - ou mandados a serem otimizados, isto é, ordenações que poderão ser satisfeitas em maior ou em menor ordem, a depender das condicionalidades fáticas e jurídicas que a circundam. Sua transmudação em direito definitivo se dará com a definição de uma relação de preferência. Relação que, por sua vez, será representada por uma regra, chamada por Alexy de regra de natureza adscrita. As regras, do contrário, ou são satisfeitas ou não são, já prevendo ordenações dentro do plano do que é fático ou juridicamente possível. Existiriam, então, duas operações para aplicar estes diferentes tipos normativos: a fórmula da subsunção, utilizada na aplicação de regras e a fórmula do sopesamento, utilizada para resolver o choque entre princípios.

Enxergando princípios como razões fundamentais para justificar e orientar a interpretação de regras, a analogia será classificada como um sopesamento das razões principiológicas alocadas no caso precedente. Nenhuma regra constante em um precedente pode ver sua aplicação estendida a um outro caso sem um balanceamento dos princípios em discussão ${ }^{69}$. É dizer, os princípios fundantes e justificadores dos precedentes delinearão a face das regras que deverão ser observadas nos casos seguintes para que a aplicação do direito ocorra coerentemente. A relação entre princípios e precedentes será, assim, mutualística, haja em conta que um sistema racional de princípios, com adequada delimitação de seu conteúdo, dependerá de um sistema coerente de precedentes ${ }^{70}$. O processo de concretização e aplicação de princípios, baseado na solução de colisões entre os

\footnotetext{
67 “Ora, é evidente que tanto no common law quanto no civil law a atitude do intérprete será predominantemente dedutiva quando houver uma regra geral a qual os fatos do caso possam ser reconduzidos pelo mecanismo da subsunção. Da mesma forma, quanto um juiz parte de uma regra que regule uma situação concreta $X$ para, por analogia, encontrar uma regulação semelhante para o caso X', será necessário encontrar por indução um princípio geral capaz de abarcar tanto o caso X quanto o caso X'." Ibid., p. 112. No mesmo sentido: VOJVODIC, op. cit., p. 93.

${ }^{68}$ ALEXY, Robert. A Theory of Constitutional Rigths. Oxford: Oxford University Press, 2002.

${ }^{69}$ BUSTAMANTE, op. cit., 2012b, p. 64.

${ }^{70}$ Ibid., p. 69.
} 
Revista Eletrônica de Direito Processual - REDP.

Rio de Janeiro. Ano 11. Volume 18. Número 1. Janeiro a Abril de 2017

Periódico Quadrimestral da Pós-Graduação Stricto Sensu em Direito Processual da UERJ

Patrono: José Carlos Barbosa Moreira. ISSN 1982-7636. pp. 377-402

www.redp.uerj.br

próprios princípios por meio da formulação de uma regra adscrita, é, a um só tempo, a linha e a agulha que irá aproximar a aplicação jurídica nos dois sistemas, uma vez que a norma para a aplicação de princípios é a mesma nas duas tradições.

A dissolução da fronteira entre direito e moral será, desta forma, acontecimento seminal para a decadência de uma separação estanque entre as formas de interpretar o direito nas diferentes tradições jurídicas.

\section{CONSIDERAÇÕES FINAIS}

O achado essencial do artigo é de que a diferença na forma como precedentes são operacionalizados nos diversos ordenamentos jurídicos não se deve em razão de uma cisão ontológica ou conceitual entre as tradições jurídicas (civil law e common law).

A seção 2 demonstrou que advogar a supremacia de determinadas fontes normativas (precedente ou legislação) a partir da diferença entre tradições jurídicas seria um ponto de partida infrutífero. Em um contexto de insuficiência da teoria das fontes sociais do positivismo clássico, tanto precedente e legislação são reconhecidos como fontes argumentativamente válidas quanto inexiste uma hierarquia estanque entre tais tipos a variar conforme a tradição jurídica. As abordagens interpretativa e argumentativa demonstraram a existência de uma relação mutualística e circular, em que a legislação condiciona a conformação dos precedentes, mas na qual os precedentes também reconstroem o sentido da legislação. A seção 3, por seu turno, discutiu o nível metodológico das duas tradições, possibilitando concluir inexistir entre elas um cisma. Se tomarmos mais uma vez como premissa teórica os desenvolvimentos pós-positivistas, a conclusão é que a harmonização entre correção e autoridade na aplicação do direito não leva a uma distinção na natureza metodológica entre as duas famílias. Banhada pela invasão do discurso moral e pela necessidade de universalizar as argumentações decisórias, as justificações de normas serão semelhantes em qualquer das latitudes teóricas.

Com tais achados, a pesquisa abre a possibilidade de que outras explicações floresçam a fim de possibilitar a compreensão dos motivos que levam países diferentes a dotar de graus normativos diferentes leis e precedentes. Uma explicação possível pode estar no aprofundamento dos estudos institucionalistas que buscam analisar e compreender o direito a partir dos pormenores concretos da institucionalidade de cada ordenamento. Outra 
Revista Eletrônica de Direito Processual - REDP.

Rio de Janeiro. Ano 11. Volume 18. Número 1. Janeiro a Abril de 2017

Periódico Quadrimestral da Pós-Graduação Stricto Sensu em Direito Processual da UERJ

Patrono: José Carlos Barbosa Moreira. ISSN 1982-7636. pp. 377-402

www.redp.uerj.br

possibilidade é ingressar numa abordagem de matriz comportamental, na qual as distinções culturais dos agentes jurídicos de cada país serviriam como chave explicativa para a concessão de feições variadas das normatividades. De forma, qualquer que seja a nova forma de abordagem, o mérito do presente artigo foi ter tentado demonstrar que não pudemos nos fiar no binômino common law/civil law para produzir explicações ontologizantes e naturalizantes sobre as diferenças na autoridade normativa e nas formas de aplicação o direito em diferentes países.

\section{REFERÊNCIAS BIBLIOGRÁFICAS:}

AARNIO, Aulis. Le rationnel comme raisonnable: la justification en droit. Paris:

Librairie Générale de Droit et de Jurisprudence, 1992.

ALEXY, Robert. Derecho y Correccíon: La Institucionalización de la Justicia, Granada: Comares, 2005.

_. A Theory of Constitutional Rigths. Oxford: Oxford University Press, 2002.

BARBOZA, Estefânia Maria de Queiroz. Stare decisis, Integridade e Segurança Jurídica:Reflexões Críticas a Partir da Aproximação dos Sistemas de Common Law e Civil Law na Sociedade Contemporânea. Tese de Doutorado. Doutorado em Direito. Pontifícia Universidade Católica do Paraná. 2011.

BUSTAMANTE, Thomas da Rosa de. A breve história do positivismo descritivo. O que resta do positivismo jurídico depois de h. L. A. Hart?. Novos Estudos Jurídicos (Online), v. 20, p. 307-327, 2015.

Teoria do Precedente Judicial: a justificação e a aplicação de regras jurisprudenciais. São Paulo: Noeses, 2012.

. Finding Analogies between Cases: On Robert Alexys Third Basic Operation in the Application of Law. In: BUSTAMANTE, T.R; PULIDO, C., B.(Org.). On the Philosophy of Precedent - Proceedings of the 24th World Congress of the International Association for Philosophy of Law and Social Philosophy, v. 3 ARCHIV FUR RECHTS-UND SOZIALPHILOSOPHIE, BEIHEFT 133. 01ed.Stuttgart: Franz Steiner Verlag, p. 59-71, 2012 b.

- A criação do direito pela jurisprudência: notas sobre a aplicação do direito e a epistemologia na teoria pura do direito. Revista da Faculdade de Direito de Uberlândia. v. 38 - n.2: 685-706, 2010. 
Revista Eletrônica de Direito Processual - REDP.

Rio de Janeiro. Ano 11. Volume 18. Número 1. Janeiro a Abril de 2017

Periódico Quadrimestral da Pós-Graduação Stricto Sensu em Direito Processual da UERJ

Patrono: José Carlos Barbosa Moreira. ISSN 1982-7636. pp. 377-402

www.redp.uerj.br

CALABRESI, G. A Common law for the Age of Statutes. Cambridge: Harvard University Press, 1982.

CROSS, Rupert e HARRIS, J.W. Precedent in English Law. 4 ed., Oxford, Clarendon, 1991

DAVID, René. Os Grandes Sistemas do Direito Contemporâneo. São Paulo: Martins Fontes, 2002.

DECOMAIN, Pedro Roberto; LEAL, João José. Súmula vinculante, regras de reconhecimento e textura aberta do Direito Análise à luz do pensamento de Herbert L.

A. Hart Resenha Eleitoral - Nova Série, v. 11, n. 1, jan.-jun. 2004.

DIMOULIS, Dimitri. A relevância prática do positivismo jurídico. Revista Brasileira de Estudos Políticos. Belo Horizonte, n. 102, pp. 215-253, jan./jun. 2011.

DOBROWOLSKI, Samantha Chantal. Justificação jurídica e sociedade na visão de Aulis

Aarnio. Dissertação (Mestrado). Universidade Federal de Santa Catarina (1997).

Faculdade de Direito. Orientador: Leonel Severo Rocha.

DWORKIN, Ronald. Ronald Dworkin and the contemporary jurisprudence. London: Duckworth, 1984.

FAIRGRIEVE, Duncan; MUIR WATT, Horatia. Common law et Tradition civiliste. Pris.

Presses. Universitaires de France/ PUF. 2006.

FON, Vincy; PARISI, Francesco. Judicial Precedents in Civil Law Systems: A Dynamic Analysis. University of Minnesota Law School Legal Studies Research Paper, $\mathbf{n}$. 07-19/ George Mason University School of Law Law and Economics Research Paper No. 04-15, 2004.

FUNKEN, Katja. The Best of Both Worlds - The Trend Towards Convergence of the Civil

Law and the Common Law System. 2013. Disponível em:<SSRN: http://ssrn.com/abstract=476461 orhttp://dx.doi.org/10.2139/ssrn.476461. Acesso em: 01 mar. 2016.

KELSEN, Hans. Jurisdição Constitucional. São Paulo: Martins Fontes, 2003.

GUEDES, Neviton de Oliveira Batista. Por que dizem que ato normativo tem duas caras?

Revista Eletrônica Conjur. Disponível em: <http://www.conjur.com.br/2015-fev03/constituicao-poder-dizem-ato-normativo-duas-caras/>.

HART, Herbert. O conceito de direito. Lisboa: Fundação Calouste Gulbenkian, 1986, p. 120. 
Revista Eletrônica de Direito Processual - REDP.

Rio de Janeiro. Ano 11. Volume 18. Número 1. Janeiro a Abril de 2017

Periódico Quadrimestral da Pós-Graduação Stricto Sensu em Direito Processual da UERJ

Patrono: José Carlos Barbosa Moreira. ISSN 1982-7636. pp. 377-402

www.redp.uerj.br

LINHARES, José Manuel Aroso. Introdução ao Pensamento Jurídico Contemporâneo.

(Manuscritos desenvolvidos para apoio à disciplina de mesmo nome no ano 2011-2012 lecionada na Faculdade de Direito da Universidade de Coimbra). Coimbra, 2012.

LORD GOFF OF CHIEVELEY, The Future of the common law. International and Comparative Law Quarterly, v. 46, 1997, p. 745-760.

MACCORMICK, Neil; SUMMERS, Robert S. Further General Reflections and Conclusions. In: MACCORMICK, Neil; SUMMERS, Robert S (Orgs.). Interpreting Precedents: A comparative Study. Aldershot: Ashgate, 1997. p. 531-549.

MACCORMICK, Neil. Legal Reasoning and Legal Theory. Oxford, Clarendon, 1978, p. 63.

MARANHÃO, Juliano. Positivismo jurídico lógico inclusivo. Madrid: Marcial Pons, 2012. MARMOR, Andrei. Prefácio. In: MARMOR, Andrei (Org). Direito e Interpretação. São Paulo: Martins Fontes, 2000, p. 4-8.

MARINONI, Luiz Guilherme. O precedente na dimensão da igualdade. 2011, p. 95. Disponívelem:<http://www.marinoni.adv.br/files_/O\%20Precedente\%20na\%20Dime ns\%C3\%A3o\%20da\%20Igualdade.docx.>.

. Aproximação crítica entre as jurisdições de civil Law e de common law e a necessidade de respeito aos Precedentes no brasil. Revista da Faculdade de Direito - UFPR, Curitiba, n.47, p.29-64, 2008.

NERY JÚNIOR, Nelson. Nery Jr. critica norma do novo CPC que obriga juiz a observar jurisprudência. Revista Consultor Jurídico. Disponível em: <http://www.conjur.com.br/2015-jul-02/nery-jr-critica-norma-obriga-juizobservar-jurisprudencia>. Acesso em: 12 dez. 2015.

POSTEMA, Gerald J. Philosophy of the Common Law. In: The Oxford Hanbook of Jurisprudence and Philosophy of Law. COLEMAN, J.; SHAPIRO, S. (Org). Oxford: Oxford University Press, 2002.

RAZ, Joseph. The Authority of Law; Ethics in the Public Domain. Oxford: Clarendon Press, 1994.

The Concept of a Legal System. 2 ed. Oxford: Clarendon Press, 1980.

SCALIA, Antonin. Common-Law Courts in a Civil-Law System: The Role of United States Federal Courts. Interpreting the Constitution and Laws. The Tanner Lectures on Human Value. Princeton University, 1995. 
Revista Eletrônica de Direito Processual - REDP.

Rio de Janeiro. Ano 11. Volume 18. Número 1. Janeiro a Abril de 2017

Periódico Quadrimestral da Pós-Graduação Stricto Sensu em Direito Processual da UERJ

Patrono: José Carlos Barbosa Moreira. ISSN 1982-7636. pp. 377-402

www.redp.uerj.br

SHAPIRO, Scott J. The "Hart-Dworkin" debate: a short guide for the perplexed. New York: Cambridge University Press, 2007.

SHECAIRA, Fábio Perin, Sources of Law are Not Legal Norms. Ratio Juris, v. 28, n. 1, pp. 15-30, 2015.

SOUZA, Marcelo Alves Dias de. The Brazilian Model of Precedents: a New Hybrid between Civil and Common law. Thesis submitted for the degree of Doctor of Philosophy King's College London - KCL The Dickson Poon School of Law. 2013.

TARRANT, S. Building Bridges in Australian Criminal Law: Codification and the Common Law, Monash University Law Review, n.39, v.3 p.838-63, p. 860-862.

TEIXEIRA, João Paulo Allain. Crise moderna e racionalidade argumentativa no direito: o modelo de Aulis Aarnio. Revista de informação legislativa, v. 39, n. 154, p. 213-227, 04/2002.

TORRANO, Bruno. Democracia e Respeito à Lei: entre o positivismo jurídico e o pós positivismo. Rio de Janeiro: Lumen Juris, 2015.

VERESHCHAGIN, Alexander. Judicial Law-Making in Post-Soviet Russia Abingdon/UK: Routledge-Cavendish, 2007, p. 113; SOUZA, Op. cit., 2013.

VOJVODIC, Adriana De Moraes. Precedentes e argumentação no Supremo Tribunal Federal: entre a vinculação ao passado e a sinalização para o futuro. 2012. $260 f$. Tese (Doutorado em Direito). Faculdade de Direito da Universidade de São Paulo, São Paulo. 